\title{
Proceeding
}

Supplementary Issue: Autumn Conferences of Sports Science. Costa Blanca Sports Science Events, 18-19 December 2020. Alicante, Spain.

\section{Self-perception of quality of life and practice of physical activity}

\author{
JORGE MANUEL FOLGADO DOS SANTOS $\triangle$, JOÃO MANUEL PATRICIO DUARTE PETRICA, JOÃO \\ JÚLIO MATOS SERRANO, MARCO ALEXANDRE DA SILVA BATISTA, SAMUEL ALEXANDRE ALMEIDA \\ HONÓRIO
}

Sport, Health and Exercise Research Unit (SHERU), Polytechnic Institute of Castelo Branco, Portugal

\begin{abstract}
Population aging is an increasingly observable fact in several developed countries. In Portugal, the percentage of elderly people is much higher compared to other age groups. We know that this phase of life causes damage at the biological level, psychological and social problems, which means that the quality of life at this age can decrease. Physical activity can be a means of reversing and / or preventing loss of quality of life. This study aims to verify whether elderly people who practice a regular program of formal physical activity have a better perception of their quality of life than non-practicing elderly people. The sample consisted of 64 elderly people $(n=64)$, residing in Proença-a-Nova in Portugal, divided into two groups, a group of practitioners in elderly programs and another group not practicing formal physical activity. The perception of quality of life was measured using the MOS SF-36v2 questionnaire, while the battery of tests by the Senior Fitness Test by Rikli and Jones (1999; 2001) was used to assess the functional level. The results showed that the perception of quality of life presents few statistically significant differences, with the highest values being that of the group of practitioners. The perception of quality of life reveals a weak correlation with the functional level presented by the two groups. It was concluded that the practice of physical activity does not influence the perception of quality of life, but it has a significant influence on a better functional level.

Keywords: Aging; Active aging; Quality of life; Physical activity.

\section{Cite this article as:}

Santos, J.M.F., Petrica, J.M.P.D., Serrano, J.J.M., Batista, M.A.S., \& Honório, S.A.A. (2021). Selfperception of quality of life and practice of physical activity. Journal of Human Sport and Exercise, 16(2proc), S289-S294. doi:https://doi.org/10.14198/ihse.2021.16.Proc2.14

Corresponding author. Sport, Health and Exercise Research Unit (SHERU), Polytechnic Institute of Castelo Branco, Portugal. https://orcid.org/0000-0002-5187-4862

E-mail: jorgesantos@ipcb.pt

Abstract submitted to: Autumn Conferences of Sports Science. Costa Blanca Sports Science Events, 18-19 December 2020. Alicante, Spain.

JOURNAL OF HUMAN SPORT \& EXERCISE ISSN 1988-5202

(c) Faculty of Education. University of Alicante

doi:10.14198/jhse.2021.16.Proc2.14
\end{abstract}




\section{INTRODUCTION}

The increase of the elderly population that has occurred in recent years, all over the world and, also in Portugal, results in several changes in society, such as the increase in the average of life expectancy and the decrease in birth rates, that's why aging has assumed an undeniable importance today (Oliveira, 2010). Rocha (2012), states that this phenomenon is reflected not only in the average life expectancy but also in the proportion of elderly people. In Portugal, according to the National Institute of Statistics (2017), the population aged 65 or over may increase from 2.1 to 2.8 million people, between 2015 and 2080. We know that aging is a process characterized by greater functional weakness, so health is an essential condition for the wellbeing of this ones. Also, the WHO (2015) reports that (...) "old age often involves significant changes in addition to biological losses. These changes include changes in social roles and positions, as well as in the need to deal with losses in close relationships" (p. 12). Seeking to provide answers to this problem, to improve the well-being and quality of life of this population, society has active aging as a means of reaching these goals. According to WHO (2002), this concept aims to optimize the possibilities of good health, participation, and security to increase the quality of life during and older age. Physical activity and formal physical activity programs have been one of the main contexts in promoting active aging, aiming to provide the elderly population with a better quality of life, mainly by maintaining their functional levels. Paulo $(2010$, p. 22) refers that there is (...) "evidence that the loss of fitness can be recovered with physical activity and that in the field of mental health, it presents psychological benefits such as the feeling of well-being". Although the existing literature tells us that formal physical activity brings several benefits, such as those mentioned above, we cannot affirm with certainty that the elderly participating in these programs have this perception. Therefore, we seek to know what they think and feel differently of their quality of life with physical activity.

\section{Objective}

The problem identified and the focus of this investigation was:

Whether these elderly population who practice a regular physical activity program have a different perception of their quality of life rather than a sedentary elderly group? In order to answer this question, we defined as a general objective to understand if elderly people who practice a regular program of formal physical activity, have a better perception of their quality of life than elderly people who do not practice it. More specifically, we also tried to find out if there were significant differences in the perception of the quality of life of elderly practitioners and non-practitioners of a regular physical activity program and, if there were any significant differences in the gender variable, between elderly practitioners and non-practitioners of a regular physical activity program.

\section{METHODS}

The study was described as quantitative, descriptive and represents a case study, in which 64 elderly people aged 65 years or more, were evaluated, all residents in Proença-a-Nova, district of Castelo Branco, Portugal, who, like other regions of the interior in this country, has been losing population with an increasing aging rating. According to data from Pordata (2018), the population density in 2001 in this region was 24.2 individuals per $\mathrm{km}^{2}$ and increased to 19.1 in 2017. The aging index increased from 245.7 in 2001 to 377.7 in 2017. The participants, characterized in Table 1, comprised a convenient sample with a total of 64 individuals $(n=64)$, having been selected by the investigator's subjective criteria, with the individuals being invited to participate voluntarily in the study. After acceptance, two groups of 32 participants were created and divided, one referred has the group of practitioners, with 32 individuals practicing physical activity in two physical activity programs for elderly (senior gymnastics and senior water aerobics), who presented an average of 
74.03 years old, 11 male and 21 females. The other group referred has the group of non-practitioners, also with 32 elderly people who did not practice any kind of formal physical activity, with an average age of 75.38 years, composed of 15 males and 17 females.

Table 1. Participants characterization.

\begin{tabular}{lcccc}
\hline Groups & N & Mean \pm SD Age (years) & Male N & Female N \\
\hline Practitioners Group & 32 & $74.03 \pm 5.93$ & 11 & 21 \\
Non-practitioners' group & 32 & $75.38 \pm 6.74$ & 15 & 17 \\
TOTAL & 64 & $74.70 \pm 6.34$ & 26 & 38 \\
\hline
\end{tabular}

In order to ensure ethical aspects, all individuals who participated in this research signed the informed consent form, agreeing to participate in all activities established by this study. For the assessment of quality of life, we used the MOS SF - 36v2 questionnaire, in the form of an interview and duly validated for application in the Portuguese population. Alves (2014) states that the application of this questionnaire aims to assess the quality of life, through the subjective perception of health status. According to Paula (2013), this questionnaire contains 36 closed-answer items, which allows the assessment of 8 dimensions. These are described by Rocha (2012) as follows: Physical function - evaluates the limitations in carrying out activities of daily living, from the basic to others more advanced; physical and emotional performance - assess health limitations, in terms of the type and amount of activity performed; Body pain - intends to assess the intensity and discomfort caused by the pain, as well as, in what way and how much it interferes with normal daily activities; General health - assesses the holistic perception of health including current health, resistance to disease and healthy appearance; Vitality - assesses energy and fatigue levels; Social function - evaluates the quantity and quality of social activities and the impact of physical and emotional problems on social activities; Mental health - concerns four of the most important dimensions of mental health, which are anxiety, depression, loss of control in behavioural or emotional terms and psychological well-being.

There is also an item referring to the transition or change in health status, which according to Rocha (2012), assesses the individual's perception of the change in health status in the last 12 months. The eight dimensions mentioned above can be grouped into two components: Physical and Mental. Paula (2013), states that the physical component includes as dimensions: physical function, physical performance, body pain and general health. The mental component includes: mental health, emotional performance, social function, and vitality. This study intended to be a "photographic portrait", of the studied population. Therefore, the application of this instrument was carried out in a single moment and on the same day. For this purpose, we have used sports pavilion, in which tables and chairs were prepared for the participants accommodation to fill out the questionnaire. After completing the informed consent form, a copy of the MOS SF - 36v2 questionnaire was given to each one of these participants. Afterwards, it was read aloud, so that everyone understood well each item. This step was performed individually. The elderly answered questions in the questionnaire as they were asked.

\section{RESULTS AND DISCUSSION}

For these results analysis, the software "IBM SPSS Statistics" version 24 was used. The normality of the sample was verified through the Shapiro-Wilk test of Kolmogorov-Smirnov. According to the data obtained, the $T$ test of independent samples was used in the case of normal distribution and the Mann Whitney test used in case normality was rejected. The analysis of our sample revealed that only the variables, physical function, and emotional performance, had a normal distribution. To measure the internal consistency of the questionnaires, we used Cronbach's alpha. Regarding acceptable reliability values, in this study, we 
considered values above 0.6, according to what was presented by Maroco and Garcia-Marques (2006), with almost all variables showing higher values, except for the social function that was 0.463 . The level of significance was set in $p<.05$.

Table 2. Mean, standard deviation and a values obtained from the questionnaire SF-36v2.

\begin{tabular}{lccc}
\hline Dimension & Practitioners group $\bar{x} \mathbf{\pm s d}$ & Non-practitioners' group $\bar{x} \mathbf{\pm s d}$ & Sig \\
\hline Physical function & $64.21 \pm 18.80$ & $51.09 \pm 25.07$ & $.036^{*}$ \\
Physical performance & $63.28 \pm 29.73$ & $52.15 \pm 29.18$ & .110 \\
Body pain & $52.72 \pm 26.17$ & $47.78 \pm 23.50$ & .397 \\
General health & $54.66 \pm 17.88$ & $50.34 \pm 16.11$ & .487 \\
Vitality & $60.16 \pm 17.73$ & $53.13 \pm 17.14$ & .065 \\
Social functional & $80.47 \pm 22.44$ & $69.14 \pm 23.09$ & $.027^{*}$ \\
Emotional performance & $60.16 \pm 32.01$ & $53.65 \pm 30.16$ & .392 \\
Mental health & $69.38 \pm 20.03$ & $66.09 \pm 19.44$ & .338 \\
Change in health & $35.16 \pm 19.94$ & $47.66 \pm 20.03$ & $.012^{*}$ \\
\hline
\end{tabular}
Note: ${ }^{*} \mathrm{Sig} \leq .05 ;{ }^{* *} \mathrm{Sig} \leq .01$.

Table 2 shows the means, standard deviation and a values of the results obtained in the SF-36v2 quality of life questionnaire. From its analysis its observable that in almost in all domains the group of practitioners obtains higher values when compared to the group of non-practitioners. The only exception is the item of change in health, in which the values are higher in the group of non-practitioners. However, we found that there are only significant differences in the variables physical function, social function, and the item of change in health. Also, in other studies carried out with this questionnaire (MOS SF - 36v2), the results point in the same direction. Camões, et al. (2016), sought to describe the perception of quality of life in individuals over 70 years of age, considering participation in physical exercise programs, with higher values in physical activity practitioners and significant differences in physical function, general health, mental health, vitality, and social function. In the study by Gomes (2010), which compared two groups of elderly people, having group that practiced physical activity and the other of non-practitioners, it was concluded that, except for the variable of body pain, in which the groups had very similar mean values, in all other dimensions it obtained significant differences, with the group of practitioners having higher values.

Table 31. Mean, standard deviation and a values obtained from the questionnaire SF-36v2 for male gender.

\begin{tabular}{lccc}
\hline Dimensions & $\begin{array}{c}\text { Practitioners group } \\
\text { Male } \bar{x} \mathbf{\pm s}\end{array}$ & $\begin{array}{c}\text { Non-practitioners' group } \\
\text { Male } \bar{x} \mathbf{\pm s d}\end{array}$ & Sig \\
\hline Physical function & $59.55 \pm 16.35$ & $49.33 \pm 26.25$ & .267 \\
Physical performance & $64.20 \pm 24.70$ & $53.75 \pm 27.12$ & .259 \\
Body pain & $66.55 \pm 26.94$ & $53.20 \pm 22.80$ & .259 \\
General health & $54.45 \pm 19.27$ & $53.20 \pm 15.45$ & .919 \\
Vitality & $61.36 \pm 18.71$ & $54.17 \pm 18.55$ & .305 \\
Social functional & $84.09 \pm 23.11$ & $74.17 \pm 21.89$ & .180 \\
Emotional performance & $59.09 \pm 29.45$ & $50.56 \pm 30.77$ & .489 \\
Mental health & $68.18 \pm 20.16$ & $72.33 \pm 20.95$ & .683 \\
Change in health & $29.56 \pm 18.77$ & $46.67 \pm 12.91$ & $.032^{*}$ \\
\hline
\end{tabular}

Note: ${ }^{*}$ Sig $\leq .05 ;{ }^{*}$ Sig $\leq .01$.

After the analyses of these results regarding the male gender, we can see in Table 3 that the average values of the variables in the SF-36v2 quality of life questionnaire are similar between the group of practitioners and 
non-practitioners. Although in almost all variables there are higher values in the group of practitioners, in mental health and in the item of change in health the opposite is found, with significant differences.

Table 4. Mean, standard deviation and a values obtained from the questionnaire SF-36v2 for female gender.

\begin{tabular}{lccc}
\hline Dimensions & $\begin{array}{c}\text { Practitioners group } \\
\text { Female } \bar{x} \mathbf{\pm s} \mathbf{d}\end{array}$ & $\begin{array}{c}\text { Non-practitioners' group } \\
\text { Female } \bar{x} \mathbf{s} \mathbf{d}\end{array}$ & Sig \\
\hline Physical function & $66.67 \pm 19.90$ & $52.65 \pm 31.78$ & .125 \\
Physical performance & $62.80 \pm 32.62$ & $50.74 \pm 29.47$ & .232 \\
Body pain & $45.48 \pm 23.21$ & $43.00 \pm 17.78$ & .642 \\
General health & $54.76 \pm 17.60$ & $47.82 \pm 12.67$ & .256 \\
Vitality & $59.52 \pm 17.64$ & $52.21 \pm 13.97$ & .107 \\
Social functional & $78.57 \pm 22.41$ & $64.71 \pm 23.06$ & .060 \\
Emotional performance & $60.71 \pm 33.97$ & $56.37 \pm 26.60$ & .669 \\
Mental health & $70.00 \pm 20.43$ & $60.59 \pm 15.70$ & $.042^{*}$ \\
Change in health & $38.10 \pm 20.34$ & $48.53 \pm 22.48$ & .161 \\
\hline \multicolumn{2}{c}{ Note: ${ }^{*}$ Sig $\leq .05 ;{ }^{* *}$ Sig $\leq .01}$. &
\end{tabular}

Regarding the female gender, we can see in Table 4 that, similarly to the male gender, the elderly women in the group of practitioners had higher average values in almost variables, except for the item of change in health. But only in the dimension of mental health, there were significant differences.

\section{CONCLUSIONS}

Physical activity in elderly is one way to fight the biological losses that individuals have at this stage of life. However, this step can also bring other types of complications. Loneliness, the end of a professional career and other common aspects that can bring psychological problems to the elderly. All these conditions can interfere with the quality of life of the elderly. Therefore, and considering that the literature tells us that in addition to physical activity, it is important to maintain and improve the functional level in an older age. It can also play an important role in quality of life, that is why we proposed with this study, to discover the answer to the following question: Do elderly people, who practice a regular physical activity program have a different perception of their quality of life than sedentary elderly people? These results came to reveal that the quality of life perceived by elderly practitioners and non-practitioners of formal physical activity is similar, tending to be higher for those who practice it, but it is not statistically significant, with the same tendency, when comparing the groups by gender.

\section{REFERENCES}

Alves, C. (2014). Percepção do estado de saúde, força muscular e composição corporal - efeito de um programa de intervenção em idosos institucionalizados. Bragança: Dissertação de mestrado Escola Superior de Saúde - Instituto Politécnico de Bragança.

Camões, M.; Fernandes, F.; Silva, B.;Rodrigues, T.; Costa N. \& Bezerra, P. (2016). Exercício Físico e qualidade de vida em idosos: diferentes contextos sociocomportamentais. Motricidade, Vol. 12 (1), 96-105. https://doi.org/10.6063/motricidade.6301

Gomes, T. (2010). Qualidade de vida, atividade e aptidão física em idosos participantes e não participantes em programas regulares de atividade física. Évora: Dissertação de mestrado Universidade de Évora. 
Instituto Nacional de Estatística, [INE], (2017), Projeções de População Residente 2015-2080. Retrieved from:

https://www.ine.pt/xportal/xmain?xpid=INE\&xpgid=ine_destaques\&DESTAQUESdest_boui=27769 5619\&DESTAQUESmodo=2\&xlang=pt

Maroco, J. \& Garcia-Marques, T. (2006). Qual a fiabilidade do alfa de Cronbach? Questões antigas e soluções modernas? Laboratório de Psicologia, Vol. 4(1), 65-90. https://doi.org/10.14417//p.763

Oliveira, M. (2010). Autopercepção do corpo: diferenças entre idosos do sexo masculino e feminino. Estudo com idosos inscritos num programa de exercício físico. Porto: Dissertação de mestrado Faculdade de Ciências do Desporto e Educação Física - Universidade do Porto.

Organização Mundial de Saúde, (OMS), (2002). Active Ageing: a policy framework. Geneva: World Health Organization. Retrieved from: https://extranet.who.int/agefriendlyworld/wpcontent/uploads/2014/06/WHO-Active-Ageing-Framework.pdf

Organização Mundial da Saúde, [OMS], (2015). Relatório Mundial de Envelhecimento Saudável. Retrieved

from: http://apps.who.int/iris/bitstream/handle/10665/186468/WHO_FWC_ALC_15.01_por.pdf;jsessionid $=067$ E6D632A507AD7E65E9F406892AC8C? sequence $=6$

Paula, A. (2013). A Qualidade de Vida dos Profissionais de Saúde Mental. Vila Nova de Gaia: Dissertação de mestrado - Escola Superior de Tecnologia de Saúde do Instituto Politécnico do Porto.

Paulo, R. (2010). Efeitos da Actividade Física não formal na Capacidade Funcional e no Índice de Massa Corporal, da População Idosa. Castelo Branco: Escola Superior de Educação - Dissertação de Mestrado - Instituto Politécnico de Castelo Branco.

Pordata. (2018). Base de dados Portugal contemporâneo- municípios. Retrieved from : https://www.pordata.pt/Municipios

Rocha, S. (2012). Efeitos do aumento da atividade física na funcionalidade e qualidade das pessoas idosas do centro social de Ermesinde. Lisboa: Dissertação de Mestrado - Faculdade de Motricidade Humana - Universidade Técnica de Lisboa.

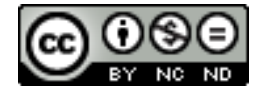

This work is licensed under a Attribution-NonCommercial-NoDerivatives 4.0 International (CC BY-NC-ND 4.0). 